Portland State University

PDXScholar

Dissertations and Theses

Dissertations and Theses

1976

\title{
Maternal and Child Health Training Assessment
}

Robert H. Abrams

Portland State University

Follow this and additional works at: https://pdxscholar.library.pdx.edu/open_access_etds

Part of the Social Work Commons

Let us know how access to this document benefits you.

\section{Recommended Citation}

Abrams, Robert H., "Maternal and Child Health Training Assessment" (1976). Dissertations and Theses.

Paper 1776.

https://doi.org/10.15760/etd.1775

This Thesis is brought to you for free and open access. It has been accepted for inclusion in Dissertations and Theses by an authorized administrator of PDXScholar. Please contact us if we can make this document more accessible: pdxscholar@pdx.edu. 


\section{MATERNAL AND CHILD HEALTH}

\section{TRA IN ING ASSESSMENT}

by

Robert H. Abrams

a research practicum submitted in partial fulfillment of the requirements for the degree of

Master of Social Work

Portland State University

1976 
TO THE OFFICE OF GRADUATE STUDIES AND RESEARCH:

The research Practicum Advisor approves the Practicum of Robert H. Abrams presented June, 1976.

Ada K. Wilson, Advisor 
TABLE OF CONTENTS

$\underline{\text { Page }}$

List of Tables ................ . . i

CHAPTERS

I. Introduction ............... I 1

History of Maternal and Child

Health Programs in the United

States

Reason for the Study ............ 3

II. Methodology. . . . . . . . . . . 4

III. Descriptive Analysis

Introduction . . . . . . . . . . 7

Section I: General Information. ........ 7

Section II: Training. . . . . . . . . 8

Section III: School of Social Work

Curriculum .......... 11

Section IV: Since Graduation........... 13

IV. Conclusions. .......... 18

APPENDIX A . . . . . . . . . . . . . 21

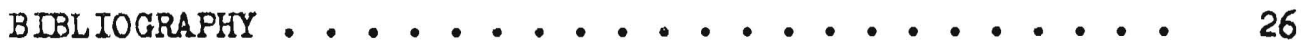




\section{LIST OF TABLES}

\section{Page}

Table I: Respondent's Opinion of

Respective Field Instructor's

Help in Three Areas:

Professional Growth, Role of

Social Work, and Case

Management. . . . . . . . . 9

Table II: How Respondents Rated Overall

Quality of Training in Their

Placements at the Medical

School. . . . . . . . . 10

Table III: Relationship between Receipt of

Stipend, Job Hold, and Dealings

in Maternal and Child Health

Content ............ 14-15 
CHAPTER I

INTRODUCTION

HISTORY OF MATERNAL AND CHILD HEALTH PROGRAMS

IN THE UNITED STATES

In the United States official responsibility for maternal and child health programs lies with federal, state, and local publio health authorities. Contributions (economic, knowledge, and service) to the field of maternal and child health are made by national voluntary agencies. Public and private hospitals are increasingly involved in the provision of community health services to mothers and children.

In this country national recognition of responsibility for child health first came about in 1912 with the creation of the United States Children's Bureau to "investigate and report on all matters pertaining to the welfare of children and child life among all classes of our people." 1

The Maternity and Infancy Act (Sheppard-Towner Act) of 1921, administered by the Children's Bureau, was the first national maternal and child health program and the first significant grant-in-aid program in the health field. Activities carried out by the Children's Bureau during the seven years of this program laid the groundwork for development of nationwide matemal and child health programs administered by the states

1. U.S. Children's Bureau, Five Decades of Action for Children, Washington, D.C., 1962. 
and set the precedent for later federal-state relationships. In 1969 , the Children's Bureau activities were transferred to a new agency, the Matermal and Child Health Service in the Health and Mental Health Administration of the Public Health Service of the Department of Health, Education and Welfare.

Schools of public health provide specialized training in maternal and child health to a variety of students who have completed professional education in their own disciplines. Content related to matemal and child health is included in the basic curricula or in special advanced programs for many of the professions involved in maternal and child health services. Federal funds administered by the Maternal and Child Health Service are used to strengthen maternal and child health teaching through faculty support and stipends for training in such fields as public health, nursing, social work, nutrition, psychology, speech and hearing, physical and occupational therapy, dentistry, and a variety of related medical specialties and sub-specialties.

Since 1947, some federal matemal and child health and crippled children's funds have been used to support speoial projects in a few graduate schools of social work with special interest in health services to children. A growing number of social work students and faculty are involved in education in maternal and child health through the affiliations of schools of social work with other professional schools and departments of universities carrying out the projects for interdisciplinary training of personnel for matemal and child health services. In 1970, 18 graduate schools of social work were involved in an interdisciplinary effort with 15 such centers. 2

2. "Progress in Matemal and Child Health," Arthur J. Lesser, Children Today, Vol. 1, No. 2, March-April, 1972, pp 7-12. 
REASON FOR THE STUDY

The School of Social Work at Portland State University has administered a Maternal and Child Health Training Project over the past ten years which has focused on two major objectives:

1) providing medically oriented social workers for the state of Oregon, and;

2) stimulating interest in maternal and child health in the field of social work.

The purpose of the study was to obtain some data in order to evaluate the degree of success experienced in realizing these objectives. The study sought to determine where the 53 graduates who have been trained through the project are employed, what aspects of their jobs relate to medical social work generally and maternal and child health concerns specifically, and what components within the currioulum content that they experienced have been particularly helpful in carrying out their tasks while working in a medically related setting. 
CHAPTER II

METHODOLOGY

Results for this study were obtained through a mail questionnaire administered to 48 of the 53 graduates who took part in the Training Project for either one or two years. Addresses were obtained through the official records of the admissions office and through informal sources.

A pre-test of the final version of the questionnaire was administered to seven of the eight second year graduate students currently placed through the Training Project at the University of Oregon Health Sciences Center. Although they could not acourately assess the section dealing with post-graduate information questions, all of the students who responded (seven of seven) stated that they thought the questionnaire to be understandable, non-biased, and designed to gain the information needed. The final version was developed with the assistance of Dr. Frank Miles, Director of the research component of the School of Sooial Work curriculum.

The general information section of the questionnaire was designed to determine when the person had graduated, whether or not he/she had received a stipend for zero, one, or two years, and where his/her field placements were located.

The training section used a combination of yes-no choices and scaled questions in order to determine each respondent's attitudes concerning his/her training during his/her field placements at the Health 
Sciences Center. Scaling questions were used in order to allow as much structured latitude in responses as possible, and the questions covered a wide range of a student's training while placed at the Health Sciences Center.

Section three, School of Social Work curriculum, was designed to obtain each respondent's opinion of the value of the curriculum in relation to maternal and child health material; as well as to assess the availability of course work dealing with maternal and child health content. Information was requested regarding what students felt should be added, dropped, and kept the same within the overall curriculum. Section four explored in what areas the graduating students have been working. Through the use of scaled, descriptive, and yes-no questions, the questionnaire sought to ascertain whether or not the graduating student had applied for a job within a medical setting, whether he/she held jobs in a medical setting, and if he/she had dealt with matemal and child health issues as a part of those jobs. Some of the questions asked if the training at the Health Sciences Center had any bearing on the choice of jobs, both in terms of training and interests. The questionnaire also sought to find out why graduates who have not worked in a medical setting chose jobs outside of the medical/matemal and child health field.

Judging from the consistency of responses between the four sections, it appears that the questionnaire was able to extract as accurate a picture as possible, given the fact that it was a mail questionnaire instead of a personal interview. Since mail questionnaires run the risk of not gaining a representative picture due to a generally low response 
rate, it is felt that the objectives of this mail questionnaire were adequately met. 3

In view of the fact that the size of this questionnaire project is so limited in terms of sample size and since one of the primary purposes is to provide supportive data for the evaluation of the effectiveness of the Training Project over the past ten years, the format of the questionnaire analysis was designed to be descriptive in nature instead of statistical. The interrelationships of the various subjects covered in the questionnaire are such that they do not readily lend themselves to statistical analysis, especially in terms of the total number of responses. Even without the more precise methodology of providing statistical support for this research project, it is thought the results of this questionnaire are nevertheless valid and worthwhile in terms of evaluating the overall impact of the Training Project.

3. Mildred Parten, Surveys, Polls and Samples, New York, Cooper Square Publishers, 1966, p. 42. 
CHAPTER III

DESCRIPTIVE ANALYSIS

\section{Introduction}

This section will provide a detailed descriptive breakdown of the questions and responses of the graduates who returned questionnaires. Following the analysis of each major question, there will be a chapter dealing with the assessment of the data, especially in terms of the effectiveness of the Training Project in achieving its goals of stimulating interest in maternal and child health issues in general and in providing medically oriented social workers for the state of Oregon.

A total of 48 questionnaires were mailed to graduates of the School of Social Work who participated in the Training Project. The total number of students who completed the Training Project (as of June 1975) is 53. Of the 48 questionnaires mailed, four were returned by the post office as undeliverable. Therefore, it is assumed that a total of 44 questionnaires were delivered to the addressees. The total response number is 31. The response rate in relation to the total number of questionnaires sent out is $64.6 \%$. The total response rate in relation to the total number of graduates who took part in the Training Project is $58.5 \%$.

\section{SECTION I}

\section{General Information}

Questions in this section asked when the student graduated, whether 
or not he/she was a grant recipient, and where his/her placements were. The breakdown of the respondents for the year of graduation showed: three graduated in 1969; three in 1970; six in 1971; seven in 1972; five in 1973; three in 1974; four in 1975.

Seven graduates received no stipend through the Training Project for either their first or second year at the School of Social Work. Six received stipends for their second year of training; and 18 received stipends for the two years of training.

A total of 12 graduates were placed with the University of Oregon Health Sciences Center during their first year of graduate sohool. Seventeen were placed at the University of Oregon Health Sciences Center during their second year, one was placed at the University of Oregon Heal th Sciences Center both years, and one did not respond to this question.

SECTION II

\section{Training}

This section asked eight major questions. Twenty-six of the respondents reported that they had rotation through services and five reported that they did not rotate through services.

All but one of the respondents reported that their staff social worker was an M.S.W.

On the question "If your field work involved rotation, what is your opinion of the utility of this method?," 12 responded that it was VERY USEFUL; 12 responded that it was SOMEWHAT USEFUL; no one stated that it was NOT USEFrU; and two did not answer. Question \#7 asked about how much time per week was spent with 
on-going case reviews with their respective field instmetor. Twenty-four responded with one-two hours per week; six responded with three hours per week; no one responded with four hours per week; and one responded with more than four hours per week. Question \#8 and the responses are shown in Table I.

TABLE I

RESPONDENT'S OPINION OF RESPECTIVE

FIELD INSTRUCTORS HELP

IN THREE AREAS: PROFESSIONAL GROWTH, ROLE OF SOCIAL WORK, AND CASE

MANAGEMIENT T

\begin{tabular}{lccc}
\hline & $\begin{array}{c}\text { Very } \\
\text { Helpful }\end{array}$ & $\begin{array}{c}\text { Somewhat } \\
\text { Helpful }\end{array}$ & $\begin{array}{c}\text { Not } \\
\text { Helpful }\end{array}$ \\
\hline Professional Growth & 22 & 6 & 3 \\
Role of Social Work & 18 & 11 & 2 \\
Case Management & 10 & 20 & 1 \\
\hline
\end{tabular}

$$
N=31
$$

Question \#9 asked the respondents to judge their training at the Health Sciences Center for their entry into professional social work. Using a five point scale question, the responses were as follows: VERY WORTHWH ILE - 14; SOMEWHAT WORTHWHILE - eight; WORTHWHILE - eight; SOMEWHAT DAMAGING - one; DAMAGING - zero. Concerning the quality of training at the Health Sciences Center, question \#10 was subdivided into three parts each employing a five point scale format. The results are shown in Table II. 
TABLE II

HOW RESPONDENTS RATED OVERALL

QUALITY OF TRA IN ING IN

THEIR PLACEMENTS

AT THE

MEDICAL SCHOOL

\begin{tabular}{|c|c|c|c|c|c|}
\hline & $\begin{array}{l}\text { High } \\
\text { Quality }\end{array}$ & Quality & Neutral & $\begin{array}{l}\text { Low } \\
\text { Quality }\end{array}$ & $\begin{array}{l}\text { Poor } \\
\text { Quality }\end{array}$ \\
\hline $\begin{array}{l}\text { Educational Opportunities } \\
\text { Hade Available }\end{array}$ & 14 & 14 & 2 & 2 & 0 \\
\hline $\begin{array}{l}\text { Encouragement to Make Use of } \\
\text { Educational Opportunities }\end{array}$ & 15 & 10 & 5 & 1 & 0 \\
\hline Feedback About Your Work & 7 & 13 & 7 & 4 & 0 \\
\hline
\end{tabular}

$N=31$ 
The final question in Section II asked how the training compared to each respondent's expectations. Responses were as follows: GREATLY EXCEEDED - three; EXCEEDED - ten; MET EXPECTATIONS - 14; FAILED TO VEET EXPECTATIONS - three; MUCH BELOW EXPECTATIONS - one.

\section{SECTION III}

School of Social Work Curriculum

Four major questions were raised in Section III. Since the structure, format, and content of the various courses offered by the School of Social Work have varied considerably over the past ten years, and since the respondents could not be expected to remember each individual course's structure, format, and content, the questions were designed to be fairly broad in scope.

Question \#12 asked whether or not courses in medical social work were offered. Thirteen responded that courses were offered and 18 responded that courses in medical social work were not offered during their educational program. Graduates from 1972, 1973, 1974, and 1975 answered that courses in medical social work were offered. No one graduating during the interval 1969 through 1971 answered that medical social work classes were offered.

Question \#13 asked how many medical social work courses were taken by each respondent. The maximum number indicated was two (five times). Fifteen indicated that they did not take any courses in medicel social work, eight indicated that they took one course, and three did not respond to the question.

Question \#14 asked "of all of your coursework, how many courses did you take which included maternal and child health content?" The break- 
down of responses is as follows: NO COURSES - three; ONE COURSE - ten; TWO COURSES - seven; THREE COURSES - fOur; NO RESPONSE - seven. Due to the number of no responses, it is assumed that some of the respondents were not able to remember whether or not maternal and child health content was offered in any of their course work. As the time since graduation increased, so did the "no response" rate.

Question \#15 asked for descriptive answere concerning medical social work and maternal and child health content within the curriculum. The respondents were asked to comment on what content they would keep, add, and drop in the curriculum. Due to the paucity of responses, no clear cut trends can be ascertained; neither can it be assessed what the respondents judged to be important in terms of curriculum content. There was a total of 21 non responses to question \#15. The answere of the ten who did respond are as follows: "What content would you keep in the curriculum?" Three indicated that they would keep all of the curriculum. Two stated that child development should be kept and five stated that evaluation, diagnosis, treatment, and understanding of family dysfunctions should be kept. There were scattered responses that discussion of death and dying, child abuse, and terminal illness should be kept. Three responded that individual instructor's classes should be kept in the course offerings. There were several responses to section "b" of question \#15, "What conent would you add?" Eight of the ten stated, in one form or another, that treatment methodology should be added to the curriculum. The range within topical content included child psychiatry, family dynamios and illness, long term chronic diseases, handicaps, emotionally disturbed children, geriatrios, parent-child interactions, high risk families, child abuse and neglect, 
and health problems with children and adults. Other issues which were presented were addition of how to understand and utilize resource systems, increasing the input from outside agency sources, and input on how to train and work on team approaches, especially in terms of working with physicians.

Only one person responded to section "c", "What content would you drop?" with a response about dropping an individual instructor's course.

\section{SECTION IV}

\section{Since Graduation}

The final section of the questionnaire, Section IV, "Since Graduation" was organized into 11 major questions and used yesmo, scaled, descriptive, and fill-in formats.

Question \#16 was divided into two parts and asked whether or not the respondent had: a) - applied for social work job(s) in medical settings; and b) - held job(s) in medical settings.

Twenty stated that they had applied for social work jobs in medical settings and 11 stated that they did not apply for jobs in medical settings. Seventeen stated that they have held jobs in medical settings.

Questions \#17 and 18 asked respondents to indicate when they had held social work jobs in medical settings. All who responded affirmatively to question \#16, with the exception of two, stated they began social work jobs in medical settings within a three month period of graduation.

If a respondent had worked, or is working in a medical setting, question \#19 asked for a brief description of the setting. The responses are included in Table III. 
TABLE $\|$

RELATIONSHIP BETWEEN RECEIPT OF STIPEND, JOB HELD, AND DEALINGS

IN MATERNAL AND CHILD HEALTH CONTENT

\begin{tabular}{|c|c|c|c|}
\hline $\begin{array}{l}\text { Stipend } \\
\text { Year } 2 \\
\end{array}$ & $\begin{array}{l}\text { Stipend } \\
\text { Year } 1 \text { \& } 2 \text { No Stipend }\end{array}$ & Job & $\begin{array}{c}\text { Maternal and Child } \\
\text { Related Work }\end{array}$ \\
\hline & $x$ & Non-medical & \\
\hline & $\mathrm{X}$ & Non-medical & \\
\hline & $\mathrm{x}$ & Non-medical & \\
\hline & $\mathrm{X}$ & Non-medical & \\
\hline & $\mathrm{X}$ & VA & Some \\
\hline & $\mathrm{X}$ & Medical Psychiatric unit & Some \\
\hline & $\mathrm{x}$ & Medical & Some \\
\hline & $\mathrm{X}$ & Non-medical & \\
\hline & $\mathrm{X}$ & Non-medical & \\
\hline & $\mathrm{X}$ & Medical & Quite a lot \\
\hline & $\mathrm{X}$ & Medical (migrant health clinic) & Quite a lot \\
\hline & $\mathrm{X}$ & Planning--medical (18 months) & None \\
\hline $\bar{x}$ & & Medical--geriatrics & None \\
\hline \multirow[t]{3}{*}{$\bar{x}$} & & Non-medical (applied) & \\
\hline & $\mathrm{X}$ & Non-medical & \\
\hline & $\bar{x}$ & Medical--nursing home SW consultant & \\
\hline \multirow[t]{3}{*}{$\mathrm{X}$} & & Adult Psychiatric/medical & \\
\hline & $\mathrm{X}$ & Non-medical (CSD) & Quite a lot \\
\hline & $\mathrm{X}$ & Non-medical (applied) & \\
\hline $\bar{X}$ & & Medical (review Title XIX team) & \\
\hline \multirow[t]{2}{*}{$x$} & & Health field--non-medical (applied) & \\
\hline & $x$ & Medical (rehabilitation spinal cord) & Very little \\
\hline
\end{tabular}


TABLE III--Continued

\begin{tabular}{cccc}
\hline \hline $\begin{array}{c}\text { Stipend } \\
\text { Year 2 }\end{array}$ & $\begin{array}{c}\text { Stipend } \\
\text { Year 1 \& 2 No Stipend }\end{array}$ & Job & $\begin{array}{c}\text { Maternal and Child } \\
\text { Related Work }\end{array}$ \\
\hline & $\mathrm{X}$ & Medical (OB-GYN abortion) & Some \\
\hline $\mathrm{X}$ & Non-medical & Quite a lot \\
\hline $\mathrm{X}$ & Medical & \\
\hline $\mathrm{X}$ & Medical (genetic--PKU) & \\
\hline $\mathrm{X}$ & Non-medical (applied) & Quite a lot \\
\hline $\mathrm{X}$ & Non-medical & Quite a lot \\
\hline $\mathrm{X}$ & Medical & Medical (OPC, surgery, Psychiatric emergency room) \\
\hline
\end{tabular}


Question \#20 asked whether or not their field placements influenced them to seek jobs in medical social work. Using a three point scale, the responses are as follows: QUTTE A LOT - 13; SOME - seven; VERY LITTLE - ten.

Question \#21 asked, "If you have held jobs in medical social work, has your work involved services to mothers and children?" Again employing a three point scale, the responses are as follows: QUITE A LOT - six; SOME - six; VERY LITTLE - six.

Questions \#22 and \#23 asked when and for how long people had work involving services to mothers and children. Since only four answered these two questions, the questions are judged to be of little value in terms of the results of this questionnaire. Questions \#24 asked for brief descriptions of respondents' work with mothers and children. The response rate was three, therefore this question is also judged to be of little value in terms of the results of this questionnaire. Question \#25 asked the respondents to rate their training at the Medical School in terms of preparing them for a job in medical social work. A five point scale was employed and the results are as follows: VERY GOOD - ten; GOOD - eight; NEUTRAL - fOur; NOT VERY GOOD - One; POOR - zero; NO RESPONSE - eight.

The final question on the questionnaire, \#26, was divided into five parts, and the results are as follows: a) - Inability to find any social work jobs due to a lack of jobs - two; b) - Inability to find a suitable job (for you) due to a lack of jobs - one; c) - A job in another field opened up which was more attractive than medical social work - ten; d) - Your experiences convinced you to not work in medical social work - four, and; e) - Other - four. 
An open-ended narrative option was provided for situations which did not fit within the four structural options listed.

Four people provided narrative comments concerning their reasons why they have not worked in medical social work settings. One person returned to Children's Services Division following an educational leave of absence. Another responded that be/she never intended to work as a medical social worker. The third respondent stated that he/she could not tolerate working with physicians and felt thet medical social workers were relegated to "dirty-work" roles. The fourth respondent reported about a detrimental experience due to a very poor relationship with his/her supervisor, and was steered away from medical social work as a result. 


\section{CHAPTER IV}

\section{CONCLUSIONS}

The jobs held by the respondents since graduation show that one of the objectives of the Training Project, to provide medical social workers, has been favorably achieved. A total of $58.6 \%$ of the respondents have held or currently hold jobs in medical social work or in the health field (18 of 31). Twenty of the respondents indicated that their field placements influenced them to seek jobs in medical social work. A total of $20(64.5 \%)$ stated that they had applied for jobs in medical settings, indicating a strong trend in one of the directions sought by the Training Program.

Thirteen people stated that they have not held jobs in a medical setting. There were ten responses that a job in another field (within social work) opened up, which was more attractive than medical social work; and four indicated that their experiences convinced them not to be employed in medical social work.

Since medical social work is a fairly specialized field, the area is not an open system with an abundance of available jobs, especially in these times of massive federal, state and local budget cut-backs on various programs. Additionally, it is noted that the School of Social Work is geared to providing generalist social workers, with the philosophy that M.S.W. graduates should be well grounded in the basics of social work and have a working understanding of the core knowledge needed to effectively practice social work on the graduate degres professional 
level. Therefore, it is acknowledged that there are several areas which graduates can enter and provide a positive contribution to the field of social work and to the needs of the medical/health field(s) as a consequence of their work in various social work settings. However, since this research project did not attempt to ascertain the extent of a person's work with medical/health concerns in jobs outside of medical social work, it can only be assumed that M.S.W.s are attempting to deal effectively with medical/health concerns as they emerge as facets of their various jobs.

The respondents were asked to indicate if their jobs in medical social work involved services to mothers and children. Twelve of the 18 individuals $(67.7 \%)$ stated that their work does involve services to mothers and children, a fact which is direotly in line with the overall goals of the Training Project.

Perhaps the most positive aspect of the Training Project, in terms of professional social work training, was provided by the placement setting at the Health Sciences Center. A majority of the students did rotation through the various services and considered that method to be VERY USEFUL (12) Or SOMEWHAT USEFUL (12).

The field instructor's preparation of the students for professional social work was rated very high by the respondents, and is an indication that the students are being trained to be competent sooial workers.

The one area relating to the training at the Health Soiences Center which did not receive a majority of positive responses was shown by the answers to case management and feedback questions. Twenty individuals indicated that field instructors were SOMEWHAT HELPFUL around oase management areas. One person answered that feedback about his/her 
work was NOT HELPFUL. Since a majority of the 24 respondents reported that they received one-two hours per week of on-going case review, it is possible that increased case review time could help to positively enhance students' opinions about case management and feedback relating to their work.

The results of the Training Project Questionnaire, while indicating that the quality of training at the Health Sciences Center was superior, also show that the curriculum in the health area at the School of Social Work was not on a par with the training received. Although the courses and course material offered by the school have been increased over the past few years (i.e., Medical Social Work, and Maternal Child Health courses), there is more course development needed in terms of offering content geared to the needs of those students who choose to pursue a specialized training relating to the health field.

In conclusion, this researcher considers the results of the Maternal Child Health Training Project questionnaire to be supportive evidence that the goals of the Project over the past ten years have been adequately met. It is recognized that the results do not show overwhelming data in favor of the total effectiveness of the Project; they do, however, give a strong indication that social workers are being well trained for work in medical settings and have a good appreciation of the needs, concerns, priorities, et. al. of the health field. It is felt that the Training Project has provided the state of Oregon with many well qualified medical social workers and has, therefore, been of great assistance to the total medical/health community in the state of Oregon. 
$\overline{\mathrm{V}} \overline{\mathrm{XI} \text { बNGddV }}$ 
MATERNAL CHILD HEALTH QUESTIONNAIRE

I. General Information

$\begin{array}{ll}\text { 1. Year/Month Graduated } & \text { 1. Year } \\ \text { 2. Grant Recipient? } & \text { 2. Month } \\ \text { First year } & \text { Yes } \\ \text { Second year } & \text { Yes } \\ \text { 3. Agency Placed } & \text { No No } \\ \text { First year } & \\ \text { Second year } \\ \text { Third year }\end{array}$

II. Training - Describe Second Year placement setting (Answer YaS or NO)

4. Rotation through Wards?

Yes

No

5. Was your staff social worker

an M.S.W.

Yes

No

6. If your field work involved rotation, what is your opinion of the utility of this method?

Very Useful Somewhat Useful Not Useful

7. Did you receive on-going case reviews with your Field Instructor?
a. 1 - 2 hours/week
Yes
No
b. 3 hours/week
Yes
No
c. 4 hours/week
d. More than 4 hours/week
Yes
No
Yes
No

8. Was your Field Instructor helpful in the following areas?

$\begin{array}{clc}\text { Very } & \text { Somewhat } & \text { Not } \\ \text { Helpful } & \text { Helpful } & \text { Helpful }\end{array}$

a. Professional Growth

b. Role of Social Work

c. Case Management 
9. Judging your overall experience at the Medical School, how would you rate the trainging for your entry into professional social work?
Very
Somewhat
Somewhat
Worthwhile Worthwhile
Damaging
Damaging

Worthwhile

10. How would you rate the overall quality of training in your placement(s) at the Medical School?
a. Educational oppor-
High
Low Poor tunities made available?
b. Encouragement to make use of educa- tional opportunities?
Quality Quality Neutral Quality Quality
c. Feedback about your work?

11. In general, how did the training compare to your expectations?

Greatly Exceeded Exceeded
Met

Expectations
Failed to

Meet Expectations
Nuch Below

Expeotations

III. School of Social Work Curriculum

12. Were courses in Nedical Social Work offered during your education program?

13. How many such courses did you take?

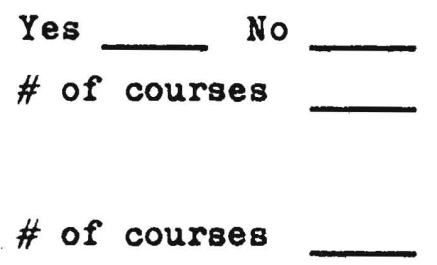

14. Of all of your coursework, how many courses did you take which included maternal and child health content?

\# of courses

15. In relation to Medical Social Work and matemal and child health casework:

a. What content would you keep in the curriculum?

b. What content would you add? 
c. What content would you drop?

IV. Since Graduation

16. Since graduation, have you:

a. Applied for social work job(s) in medical settings?

b. Held job(s) in medical setting

17. When? (Dates)

18. Year and month

Yes

No

Yes No

From To

Year Month

19. Give brief description of setting(s). (EXAMPLE: VA Hospital; General Medicine Ward)

20. Did your field placement influence you to seek a job with Medioal Social Work?

Quite A Lot

Some

Very Little

21. If you have held jobs in Medical Social Work, has your work involved services to mothers and children?

Quite A Lot

Some

Very Little

22. When?

From To

23. How Long?

24. Give brief description: 
25. How would you rate the training at the Medical School in terms of preparing you for a job in Medical Social Work?

Very Good Good Neutral Not Very Good Poor

26. If you have not worked in a Medical Setting since graduation (for more than a summer), would you please explain why?
a. Inability to find any social work jobs due to a lack of jobs?

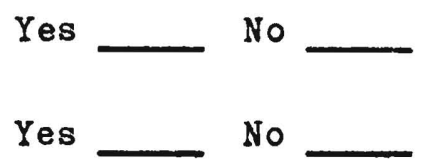
b. Inability to find a suitable job (for you) due to a lack of jobs?
c. A job in another field opened up which was more attractive than medical social work?

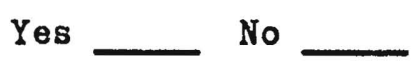
d. Your experiences convinced you to not work in medical social work?
Yes
e. Other 


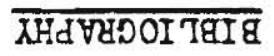




\section{BIBLIOGRAPHY}

Medical Social Services for Children, Washington, D.C., U.S. Childrens Bureau, 1953.

"Health Services: Maternal and Child Health," Encyclopedia of Social Work, N.A.S.W., New York, 1971, Vol. 1.

"Progress in Matemal and Child Health," Arthur J. Lesser, Children Today, Vol. 1, No. 2, March-April, 1972, pp 7-12.

Surveys, Polls, and Samples, Mildred Parten, New York, Cooper Square Publishers, 1966, p. 42. 